\title{
Flipped Learning Model: Satu Cara Alternatif untuk Meningkatkan Keterampilan Berbicara Siswa
}

\section{The Flipped Learning Model: An Alternative Way to Enhance Students' Speaking Skills}

\author{
Julinar', Fazri Nur Yusuf ${ }^{2}$ \\ ${ }^{1}$ Guru SMAN 1 Rantau Kopar, Kab. Rokan Hilir, Riau, Indonesia \\ ${ }^{2}$ Universitas Pendidikan Indonesia, Bandung, Jawa Barat, Indonesia \\ julinar@upi.edu
}

Naskah diterima tanggal 21/10/2019, direvisi akhir tanggal 05/12/2019, disetujui tanggal 23/12/2019

\begin{abstract}
Abstrak
Pengurangan jam mengajar bahasa Inggris dalam penerapan kurikulum 2013 menimbulkan beberapa masalah karena guru tidak memiliki cukup waktu untuk menyampaikan semua konten pelajaran dan memfasilitasi kegiatan siswa. Pembelajaran terbalik adalah salah satu pendekatan pengajaran yang bisa menjadi alternatif dalam menghadapi kekurangan jam mengajar. Penelitian ini bertujuan untuk mengetahui penerapan flipped learning model/pembelajaran terbalik dalam meningkatkan keterampilan berbicara siswa dan bagaimana respon siswa terhadap penerapan flipped learning model. Speaking test, observasi dan semi structured interview digunakan untuk mengumpulkan data. Hasil penelitian menunjukkan bahwa flipped learning model dapat meningkatkan keterampilan berbicara siswa dan siswa merespon positif penerapan flipped learning model sebagai salah satu cara belajar yang efektif. Penerapan flipped learning model membuat siswa menjadi lebih percaya diri untuk berbicara bahasa Inggris dan meningkatkan prestasi belajar mereka.
\end{abstract}

Kata kunci: model pembelajaran terbalik, keterampilan berbicara.

\begin{abstract}
The reduction of English teaching hours in the implementation of curriculum 2013 raises some problems as teachers do not have enough time to deliver all the contents and facilitating students 'activities. Flipped learning is one of the teaching approaches that can be an alternative in facing a shortage of instructional hours. This study aims to investigate the challenges and students' responses toward the implementation of the flipped learning model in enhancing students'speaking skills. Semi-structured interviews and observation were employed to collect data. The results showed that the flipped learning model increased students' speaking skills and students' motivation. Regarding speaking skills, it revealed that students became more confidence to speak English and improved their learning achievement.
\end{abstract}

Keyword: flipped learning model, speaking skills.

\section{PENDAHULUAN}

Pengurangan jam mengajar bahasa Inggris dalam penerapan kurikulum 2013 di sekolah menengah atas telah memengaruhi keberhasilan pengajaran bahasa asing di Indonesia. Dengan hanya dua jam per minggu, guru mengalami kesulitan untuk mencapai indikator pada rencana pembelajaran dan silabus. Karim \& Abdul (2011) mencatat bahwa banyak guru bahasa Inggris di Indonesia secara dominan lebih banyak menghabiskan waktu mengajar untuk mengembangkan dua keterampilan reseptif (membaca dan mendengarkan) karena keterampilan ini diuji dalam Ujian Nasional. Sehingga, guru menyediakan lebih sedikit 
waktu untuk mengembangkan keterampilan bahasa Inggris produktif (berbicara dan menulis).

Pendekatan tradisional yang berfokus pada hafalan atau penerapan prosedur sederhana tidak banyak mengembangkan kompetensi siswa terutama keterampilan berbicara. Sementaraitu, pada konteks Bahasa Inggris sebagai bahasa asing EFL (Englsih as Foreign Language) seharusnya memberikan banyak peluang untuk menggunakan bahasa Inggris di luar kelas, (Bax, 2003; Humphries \& Burns, 2015; Kumaravadivelu, 1993; Li, 1998). Bahkan dalam pendekatan pengajaran 'communicative approach' masih banyak waktu mengajar yang digunakan oleh guru secara tidak efektif yangb hanya fokus mengajarkan konsep. Sementara siswa diamdiam duduk dan mendengarkan secara pasif, (Lee, 2009; Littlewood, 1999). Ini seharusnya mulai dirubah oleh guru. Wells, et al (2008) mengemukakan bahwa kemajuan teknologi telah mengubah cara guru mengajar dan siswa belajar. Saat ini guru perlu mengintegrasikan teknologi ke dalam pengajaran mereka, memanfaatkan kelebihannya secara maksimal untuk mencapai tujuan pembelajatran. Intergrasi teknologi dalam pembelajaran akan menciptakan ruang belajar yang lebih baik bagi siswa mereka (Koehler et al., 2004).

Flipped learning model atau yang disebut kelas terbalik adalah salah satu model pembelajaran yang mengintegrasikan metode pengajaran berbasis teknologi. Model ini telah menarik perhatian para guru dan peneliti karena keunggulannya. Flipped learning model memberikan kesempatan bagi siswa untuk belajar secara mandiri baik di dalam maupun di luar kelas. Wiginton (2013) menyatakan bahwa flipped learning adalah model pembelajaran yang menggunakan teknologi dengan mengubah tempat belajar yang biasanya hanya didalam kelas, menjadi diluar kelas bahkan dimana saja.

Flipped learning model lebih memfokuskan siswa pada kegiatan pembelajaran yang lebih mendalam (Bergmann \& Sams, 2012; Hamdan et al., 2013; Honeycutt \& Garrett, 2014). Melalui model pembelajaran ini, kegiatan pembelajaran yang biasanya dilakukan dikelas diganti menjadi pekerjaan rumah dengan bantuan teknologi, sementara untuk kegiatan belajar didalam kelas dilakukan lebih bervariasi sepeerti diskusi, tanya jawab, presentasi dan kegiatan komunikatif lainnya as dengan panduan guru. Dengan kata sederhana, dapat dikatakan bahwa flipped learning model adalah apa yang dilakukan kelas, beralih untuk dilakukan di luar kelas.

Flipped learning model terdiri dari lima elemen; 1) Siswa aktif dalam pembelajaran; 2) Teknologi memfasilitasi proses belajar langsung; 3) Mempelajari materi secara online sebelum menghadiri kelas; 4) Masalah dunia nyata ditugaskan kepada siswa; dan, 5) Kegiatan didalam kelas difokuskan untuk kegiatan diskusi dan komunikatif lainnya yang langsung dipandu oleh guru (Becker 2013; Davies, et al. 2013). Ada beberapa penelitian terkait yang telah dilakukan tentang penerapan flipped learning model. Penelitian pertama adalah dari Danker (2015), ia menyelidiki penggunaan pendekatan flipped learning model untuk mengeksplorasi pembelajaran secara intensif di kelas besar. Penelitian melibatkan 33 siswa dari kelompok tahun pertama diploma jurusan seni. Hasil penenlitian menunjukkan bahwa dengan flipped learning model, siswa menjadi pembelajar aktif dan peran guru beralih menjadi fasilitator dengan memulai diskusi kelas untuk memastikan bahwa semua siswa mendapat pemahaman lebih pembelajaran lebih bermakna dan lebih efektif.

Peneltian kedua dilakukan oleh Jamie (2010). Dia melakukan penelitian tindakan kelas untuk mengeksplorasi penggunaan teknologi dalam mempersiapkan siswa untuk presentasi lisan. Siswa dari kelompok eksperimen menggunakan flipped learning dengan menggunakan kamera untuk mempersiapkan presentasi mereka di mana teman sekelas saling merekam satu sama lain dan mereview hasil klip video tersebut dengan saling memberi komentar satu sama lain. Sementara siswa dari kelompok kontrol menggunakan cara pengajaran tradisional. Studi ini mengungkapkan bahwa penggunaan 
flipped learning model selama persiapan membuat siswa lebih percaya diri.

Ketiga menurut Farangi, et al (2015) mempelajari pengaruh flipped learning model dalam bentuk podcasting pada enam puluh peserta didik dikelas speaking/berbicara pada kontek EFL. Siswa - siswa dibagi menjadi tiga kelompok, dua kelompok eksperimen dan satu kelompok kontrol. Kelompok eksperimental pertama terlibat dalam pembuatan podcast dengan diskusi kelompok dan mengunggahnya ke layanan podcasting. Kelompok eksperimen kedua menggunakan podcast berbasis web yang terkait dengan topik diskusi mereka. Sementara kelompok kontrol mengikuti pengajaran bahasa komunikatif. Hasil penelitian ini menunjukkan bahwa flipped learning dalam bentuk podcasting buatan siswa memiliki efek positif pada keterampilan berbicara siswa lebih dari dua kelompok lainnya. Berdasarkan teori dan fakta yang dijelaskan diatas, Penelitian ini dilakukan untuk melihat bagaimana penerapan flipped learning model dalam meningkatkan keterampilan berbicara siswa dan apa persepsi siswa terhadap penerapannya.

\section{METODOLOGI PENELITIAN}

Penelitian ini menggunakan desain metode campuran / mixed methods yang berfokus pada pengumpulan, analisis, dan pencampuran data kualitatif dan kuantitatif dalam dalam satu studi (Hamied, 2017). Dengan demikian, desain ini digunakan untuk mengukur tidak hanya hasil penelitian tapi juga proses yang terjadi selama penelitian dilakukan. Pengumpulan data dilakukan dengan menyelenggarakan speaking pretest dan posttest, observasi, dan 'semi structured interview' (Creswell, 2012).

Penelitian ini akan dilakukan di salah satu SMAdi Bandung. Partisipannya melibatkan siswa kelas XI yang terdiri dari 33 orang siswa. Untuk mengumpulkan data, peneliti menggunakan beberapa teknik yaitu; tes berbicara, observasi kelas, dan 'semi structured interview'. ketiga teknik ini digunakan untuk mendukung validitas konstruk penelitian (Yin, 2003)

Ada enam topik yang akan dibahas selama flipped learning model diimplementasikan, seperti yang disajikan dalam tabel 1 sebagai berikut:

Tabel 1. Rencana pelajaran

\begin{tabular}{ccl}
\hline Pertemuan 1 & $\begin{array}{c}\text { Jumlah } \\
\text { pertemuan }\end{array}$ & \multicolumn{1}{c}{ Topik } \\
\hline 1 & 1 & The importance of breakfast \\
\hline 2 & 1 & Internet effect \\
\hline 3 & 1 & Homework \\
\hline 4 & 1 & Hate speech comments on social media \\
\hline 5 & 1 & National Examination for students \\
\hline 6 & 1 & Library, is it important? \\
\hline
\end{tabular}

Data dari tes berbicara dihitung secara kuantitatif menggunakan statistik SPSS, sementara data dari observasi kelas dan semi struktur wawancara dijelaskan secara kualitatif sesuai dengan rekaman selama penelitian dan transkrip hasil wawancara.

III. HASIL DAN PEMBAHASAN

3.1 Hasil

a. Hasil tes Berbicara

Tabel 2. Hasil Uji Sampel Berpasangan

\begin{tabular}{|c|c|c|c|c|c|c|c|c|c|}
\hline & & \multicolumn{5}{|c|}{ Paired Differences } & \multirow{3}{*}{$t$} & \multirow{3}{*}{$d f$} & \multirow{3}{*}{$\begin{array}{c}\text { Sig. } \\
\text { (2-tailed) }\end{array}$} \\
\hline & & \multirow[t]{2}{*}{ Mean } & \multirow[t]{2}{*}{$\begin{array}{c}\text { Std. } \\
\text { Deviation }\end{array}$} & \multirow[t]{2}{*}{$\begin{array}{l}\text { Std. } \\
\text { Error } \\
\text { Mean }\end{array}$} & \multicolumn{2}{|c|}{$\begin{array}{c}\text { 95\% Confidence } \\
\text { Interval of the } \\
\text { Difference }\end{array}$} & & & \\
\hline & & & & & Lower & Upper & & & \\
\hline Pair 1 & $\begin{array}{l}\text { pretest - } \\
\text { posttest }\end{array}$ & -13.030 & 6.724 & 1.171 & -15.415 & -10.646 & -11.132 & 32 & .000 \\
\hline
\end{tabular}


Tabel 2 menunjukkan bahwa ada peningkatan selama flipped learning model diterapkan dalam pengajarana speaking/ berbicara.Hasil statistik ini juga menegaskan bahwa penerapan flipped learning model memiliki efek positif yang signifikan terhadap peningkatan keterampilan berbicara siswa.

Berdasarkan hasil SPSS, signifikansinya adalah $0,000(\mathrm{p}=0,000)$ yang lebih rendah dari 0,05 atau $0,000<0,05$. Ini berarti bahwa hipotesis nol ditolak dan terjadi peningkatan yang signifikan dari penerapan flipped learning model dalam meningkatkan keterampilan berbicara siswa.

Selain itu, setelah penerapan flipped learning model, terdapat beberapa aspek berbicara yang mengalami porsi peningkatan lebih banyak dalam hal peningkatan berbicara siswa. Tabel 4 di bawah menyajikan skor total siswa dalam setiap aspek yang diperoleh dari hasil tes berbicara selama penelitian.

Tabel 3. Peningkatan Siswa dalam Lima Elemen Berbicara

\begin{tabular}{lcc}
\hline \multicolumn{1}{c}{ Speaking Elements } & $\begin{array}{c}\text { Pretest } \\
\text { (rater 1 and rater 2) }\end{array}$ & $\begin{array}{c}\text { Positest } \\
\text { (rater 1 } \text { and rater 2) }\end{array}$ \\
\hline Grammar and vocabulary & 350 & 445 \\
\hline Content & 350 & 500 \\
\hline Pronunciation & 340 & 340 \\
\hline Fluency & 335 & 480 \\
\hline Interactive communication & 295 & 335 \\
\hline
\end{tabular}

Tabel 3 diatas menunjukkan bahwa setelah penerapan flipped learning model, peningkatan yang paling dominan terjadi ada pada aspek penguasaan konten dengan nilai total (500) dan aspek kelancaran dengan nilai total (480). Dipastikan bahwa penerapan flipped learning model dapat menjadi satu cara alternatif untuk meningkatkan keterampilan berbicara siswa terutama dalam hal penguasaan konten dan kelancaran berbicara.

\section{b. Respon Siswa terhadap Implementasi Flipped Learning Model}

Untuk mengetahui keberhasilan implementasi flipped learning model. Respon siswa selama penerapan model ini dilakukan melalui wawancara. Sembilan orang perwakilan siswa diwawancarai untuk mendapatkan informasi terperinci dari penerapan model ini. Pertanyaan wawancara terdiri dari sepuluh item semi-terstruktur yang mencakup lima tema yaitu; pendapat siswa tentang implementasi flipped learning model, persepsi siswa terhadap pembelajaran online, tingkat keterlibatan siswa, persepsi terhadap kegiatan speaking dikelas, dan persepsi terhadap kendala-kendala yang terjadi selama penerapan flipped learning model dalam meningkatkan keterampilan berbicara siswa.

\section{c. Respon siswa terhadap penerapan model pembelajaran terbalik.}

Meskipun sebagian besar siswa tidak memiliki pengalaman tentang flipped learning model dan cara penggunaannya, sebagian besar siswa berpendapat positif terhadap penerapan model pembelajaran terbalik ini dalam meningkatkan keterampilan berbicara mereka. Dari komentar wawancara, sebagian besar siswa sepakat bahwa model pembelajaran terbalik memungkinkan mereka untuk mempersiapkan kelas di muka. "Saya tidak pernah tahu model pembelajaran flipped sebelumnya, tetapi saya suka model flipped learning karena saya bisa belajar banyak hal dari video sebelum datang ke kelas. Saya berlatih mengucapkan kalimat berbahasa Inggris. Saat di kelas saya bersama teman-teman berbagi pendapat dengan mereka".

\section{d. Respon siswa terhadap pembelajaran online}

Karena flipped lerning model menyediakan materi melalui pembelajaran online, ini ternyata menjadi model inovatif yang memberi pengalaman belajar yang baru kepada siswa. Model pembelajaran terbalik memungkinkan siswa untuk memiliki lingkungan belajar yang lebih interaktif. 
Guru berperan mempersiapkan siswa untuk mengikuti pelajaran dan kegiatan berbicara yang dilakukan dalam sesi kelas offline. Siswa diindtruksikan mempelajari materi sebelum kelas offline guna memperoleh pengetahuan awal tentang topik yang akan didiskusikan dan mereka menjadi lebih percaya diri kegiatan berbicara saat kelas offline. Seorang siswa berkata,

"Ketika saya tahu guru saya mengunggah pelajaran video di Edpuzzle. Saya sangat menyukainya, saya bisa belajar di mana saja, memutar ulang materi sebanyak yang saya butuhkan. Jadi saya tahu topiknya, saya punya pendapat tentang topik itu, dan saya bisa meniru cara pembicara berbicara. Itu sangat membantu saya".

e. Keterlibatan siswa dalam model pembelajaran terbalik

Ketika ditanya apakah flipped learning model membuat siswa lebih melibatkan mereka secara sadar dan aktif untuk belajar, sebagian besar peserta menjawab bahwa mereka merasa terlibat dan senang dengan metode baru ini. Siswa mengkonfirmasi bahwa sampel video pembelajaran yang diposting guru telah membantu mereka memahami pelajaran dengan lebih baik dan kemudian merasa percaya diri untuk berpartisipasi dalam kegiatan di kelas. Mereka juga menambahkan bahwa mereka dapat belajar dengan menonton video pembelajaran kapan saja dan di mana saja, dan sebanyak yang mereka inginkan.

"Karena saya memiliki pelajaran video di ponsel saya, video itu mengingatkan saya bahwa saya harus menonton video itu dan melengkapi quiz-quiz dari video. Itu membuat saya selalu ingat untuk mempersiapkan diri untuk tampil lebih baik di kelas berbicara besok".

\section{f. Tanggapan siswa terhadap kegiatan berbicara/speaking}

Meskipun siswa menganggap bahwa keterampilan berbicara sangat penting, mayoritas siswa di kelas itu berpendapat bahwa bicara berbahasa Inggris adalah keterampilan yang sangat sulit. Para siswa sepakat bahwa penerapan flipped learning model dapat meningkatkan kemampuan berbicara mereka dan menjadi terlibat aktif dalam menyiapkan pembelajaran untuk kelas selanjutnya. Mereka menganggap bahwa model pembelajaran terbalik telah memberikan peluang untuk bisa berlatih berbicara, ketika di dalam kelas maupun di luar kelas.hal itu dimulai saat mereka menonton video pelajaran di Edpuzzle dan melengkapi pertanyaan dari video tersebut. Mereka mendapatkan paparan input sebelum memasuki kelas speaking.

"Saya dengan percaya diri tampil di depan kelas. Dari video-video itu saya tahu apa yang harus dibicarakan, bagaimana berbicara dalam bahasa Inggris karena topik-topik yang dibahas akrab dengan kehidupan saya sehari-hari. Saya merasa termotivasi untuk belajar lebih giat".

g. Respons siswa terhadjap kendalakendala yang dihadapi selama peberapan flipped learning model

Meskipun model pembelajaran terbalik memberi banyak pengaruh positif dalam meningkatkan keterampilan berbicara siswa, penerapan flipped learning model ini juga menghadirkan beberapa kendala baik dalam aktivitas online maupun offline. Dalam kegiatan online, beberapa siswa mengatakan bahwa mereka masih terbiasa dengan gaya belajar tradisional sehingga mereka membutuhkan lebih banyak waktu untuk bisa terbiasa menggunakan metode baru ini. Beberapa orang siswa mengatakan bahwa sering sekali menghadapi beberapa masalah yang berkaitan dengan masalah teknis saat log in di aplikasi Edpuzzle disebabkan koneksi internet yang sewaktu-waktu kurang baik.

"Terkadang koneksi internet tidak berfungsi dengan baik. Butuh waktu lama untuk masuk lagi ke Edpuzzle. Saya akhirnya menghentikan tugas online saya"

\subsection{Pembahasan}

Temuan yang paling menonjol dari penelitian ini adalah bahwa penerapan flipped learning model mampu meningkatkan 
keterampilan berbicara siswa dalam beberapa aspek, yang paling dominan adalah dalam aspek kefasihan dan penguasaan konten. Hasil speaking postest menunjukkan bahwa siswa yang telah diajar menggunakan flipped learning model meraih peningkatan kemampuan berbicara bahasa Inggris dan memiliki tanggung jawab belajar yang lebih baik.

Meskipun skore peningkatan keterampilan berbicara siswa tidak terlalu tinggi, namun peerapan flipped learning model disukai karena meningkatkan siswa aspek lain dari pembelajaran mereka. Ini terlihat saat penerapan flipped learning yang berlangsung selama tujuh minggu. Persiapan awal yang dilakukan dengan mempelajari video pembelajaran sebelum masuk kelass offline memberikan kesempatan bagi siswa untuk meningkatkan keterampilan berbicara mereka, terutama dalam beberapa aspek seperti; kosakata dan tata bahasa, penguasaan konten, pengucapan, kelancaran dan komunikasi interaktif.

Temuan ini juga menjelaskan bahwa manfaat dari flipped learning model sangat dirasakan oleh siswa sebagai upaya untuk menciptakan lingkungan belajar yang memberi waktu luang lebih banyak untuk bisa fokus belajar secara lebih baik dalam meningkatkan kemampuan berbicara bahasa Inggris. Selain itu, siswa juga merasa lebih termotivasi, merasa lebih bertanggung jawab untuk terlibat dalam melengkapi tugas-tugas dari guru. Siswa juga menganggap flipped learning model lebih fleksibilitas dalam menggunakan waktu belajar mereka. Ini menegaskan bahwa flipped learning model dapat menjadi satu alternatif dalam mengajar speaking skills karena membuat siswa lebih mandiri belajar (Schultz et al., 2014).

Data dari wawancara menunjukkan bahwa siswa memiliki tanggapan positif terhadap penerapan flipped learning model. Tanggapan positif ini disebabkan dalam model pembelajaran online terbalik, mereka dapat mengkases pelajaran tanpa mendapat tekanan dari orang lain dan campur tangan siswa lain. Mereka juga termotivasi karena mereka memiliki gaya dan pengalaman belajar baru, sehingga mereka menjadi lebih tertantang dalam proses pembelajaran. Selanjutnya, dari pembelajaran offline mereka berbicara lebih aktif dari biasanya meskipun mereka menyadari bahwa mereka membuat kesalahan berkali-kali. Ketika guru senantiasa memberikan umpan balik secara positif, maka siswa akan melakukan upayaupaya untuk memperbaiki kesalahan meraka. Hasil ini sejalan dengan temuan penelitian sebelumnya yang dilakukan oleh (Gupta, et al. 2019; Ginola \& Magdalena 2016). Mereka menyatakan bahwa siswa-siswa sepakat flipped learning model memberikan pengalaman belajar yang inovatif dalam meningkatakan keterampilan berbicara berbahasa Inggris mereka.

\section{KESIMPULAN}

Tujuan utama dari penelitian ini adalah untuk mengetahui implementasi atau penerapan flipped learning model untuk meningkatkan keterampilan berbicara siswa. Temuan penelitian ini mengungkapkan bahwa model pembelajaran terbalik/ flipped learning mampu meningkatkan keterampilan berbicara siswa terutama dalam hal ketrampilan penguasaan konten dan kefasihan berbicara. Belajar melalui video pembelajaran dan bahan bacaan lain yang berisi topik yang berkaitan erat dengan kehidupan mereka sendiri sangat membantu para siswa untuk mempersiapkan diri sebelum menghadiri aktifitas speaking ke kelas. Duarte \& Jurado (2008) menyebutkan hal yang sama bahwa siswa dapat lebih meningkatkan keterampilan mereka melalui pembelajaran berbasis audio visual. Penggunaan audio visual juga dalam pembelajaran akan meningkatkan keterampilan komunikasi siswa secara efektif. Dengan demikian, dapat disimpulkan bahwa model pembelajaran terbalik adalah model yang efektif untuk meningkatkan keterampilan berbicara siswa.

Data dari wawancara menunjukkan bahwa siswa memiliki tanggapan positif terhadap penerapan flipped learning model di kelas speaking mereka. Meskipun model ini masih baru bagi mereka, mereka secara aktif terlibat dalam sesi online dan offline. 
Mereka tidak malu untuk tampil berbicara di depan kelas, dan memiliki rasa gugup yang lebih sedikit dari sebelumnya. Mereka merasa lebih bertanggungjawab mempersiapkan diri mempelajari materi pelajaran dan melengkapi tugas-tugas lainnya. Pada akhirnya, pengetahuan mereka terbangun dan berkembang melalui informasi yang ada di video-video pembelajaran yang diberikan. Siswa-siswa juga dapat meningkatkan kemampuan pengucapan kosakata bahasa
Inggris dengan pelafalan yang benar setelah meniru pengucapan pembicara yang ada di video. Selain itu, mereka menjadi lebih percaya diri untuk berbicara didepan umum karena mereka memiliki pengetahuan yang diperoleh sebelumnya dan mampu mengucapkan katakata berbahasa Inggris secara benar. Mereka berharap bahwa flipped learning model akan diterapkan di semua kelas bahasa Inggris dan mata pelajaran lainnya.

\section{DAFTAR RUJUKAN}

Bax, S. (2003). The end of CTL: A context approach to language teaching. ELT Journal, 57, 278-287, doi:10.1093/ elt/57.3.278.

Becker, B. W. (2013). Start flipping out with guide on the side. Behavioral \& Social Sciences Librarian. 32(4). 257-260. doi:10.1080/01639269.2013.838879

Bergmann, J., \& Sams, A. (2012). Flip Your Classroom: Reach Every Student in Every Class Every Day. Washington DC: International Society for Technology in Education.

Burns, A., \& Joyce, H. (1997). Focus on speaking. Sidney: National Center for English Language Teaching and Research.

Creswell, J. W., (2012) John W. Educational research Planning, Conducting and Evaluating Quantitative and Qualitative Research, Fourth Edition. Boston: Pearson 2012.

Danker, B. (2015). Using Flipped Classroom Approach to Explore Deep Learning in Large Classrooms. IAFOR Journal of Education, V 3(1), hal 171-186.

Davies, R. S., Dean, D. L., \& Ball. (2013). Flipping the classroom and instructional technology integration in a college-level information systems spreadsheet course. Educational Technology Research and Development, 61(4), 563-580.doi:10.1007/s 11432-013-930506.

Duarte, J., \& Jurado, J. C. (2008). Pedagogical processes and their school coexistence relationship. Revista Colombiana de Educación, 55, 62-81.

Farangi, M., Nejadghanbar, H., Askary, F., \& Askary, F. (2015). The effect of podcasting on EFL upper-intermediate learners, speaking skills. CALL-EJ. 16(2): 1-18.

Gupta, V., Datta, P., Gupta, M., \& Singh, M. (2019). Use of Flipped model classroom teaching on learning of Immunology in second professional Medical Students. South-East Asian Journal of Medical Education, Vol. 13, hal: 39-45.

Ginola, D., \& Magdalena, D. (2016). The Implementation of Flipped Classroom by Using Schoology in Speaking II Class of English Education Study Program of Teacher Training and Education Faculty of Bandar Lampung University. [Proceedings]. The Fourth International Conference on Education and Language (4th ICEL). Hal 199-207.

Honeycutt, B., \& Garrett, J. (2014). Expanding the Definition of a Flipped Learning Environment. [Online]. Diakses dari: https://www.facultyfocus.com/articles/blended-flipped-learning/expanding-definitionflipped-learning-environment/.

Hamdan, N., Mc Knight, P. E., Mc Knight, K., \& Arfstrom, K. M. (2013). A white paper based on the literature review: A review of flipped learning. [Online]. Diakses dari: http://www.flippedlearning.org/cms/lib07/ VA01923112/Centricity/Domain/41/WhitePaper_FlippedLearnin.pdf.

Hamied, F. A. (2017). Research Method: A Guide for first-time researchers. Bandung: UPI Press.

Humphries, S., \& Burns, A. (2015). In reality it's almost impossible: CLT-oriented curriculum change. ELT Journal, Vol: 69, Hal 239-248. Doi:10.1093/elt/ccu081.

Jamie,L.B.,(2010). UsingTechnologytoEnhancePublicSpeakingandLowerAnxietyinStudents. [Online].Diaksesdari: https://www.google.com/url?sa=t\&rct=j\&q=\&esrc=s\&source=web\&cd=1\&ved=2ahUKEwj6jKr4x $8 \mathrm{Hm}$ AhVTWX0KHcwzATMQFjAAegQIAxAC\&url=https\%3A\%2F\%2Fsj.ctu.edu.vn $\% 2$ Fql $\% 2$ Fdocgia $\% 2 F$ download\%2Fbaibao-44084\%2F12-ED-TRAN\%2520THI\%2520THANH\%2520QUYEN(90-97)012.pd f\&usg=AOvVaw1CkYevwEygWixopYsSvFyR 
Schultz, D., Duffield, S., Rasmussen, S. C., \& Wageman, J. (2014). Effects of the Flipped Classroom Model on Student Performance for Advanced Placement High School Chemistry Students. Journal of Chemical Education, Vol 91 (9), hal: 1334-1339.

Karim, M., \& Abdul R H. (2011). The Teaching Constraints of English as a Foreign Language in Indonesia: The Context of School Based Curriculum. SOSIOHUMANIKA Article, Vol. 4 (2), hal 295.

Koehler, M. J., Mishra, P., Hersley, K., \& Peruski, L. (2004). With a Little Help from Your Students: A New Model for Faculty Development and Online Course Design. Journal of Technology and Teacher Education, 12 (1), 25-55.

Kumaravadivelu, B. (1993). Maximizing learning potential in the communicative classroom. ELT Journal, 47, 12-21.

Lee, G. (2009). Speaking up: six Korean students' oral participation in class discussion in US graduate seminars. English for Specific Purposes, Vol: 28, hal: 142-156.

Littlewood, W. (1999). Defining and Developing Autonomy in East Asian Contexts. Applied Linguistics, Vol: 20, hal: 71-94.

Li, D. (1998). It is always more difficult than you plan and imagine: Teachers' perceived difficulties in introducing the communicative approach in South Korea. TESOL Quarterly, Vol: 32, hal: 677-703.

Ur, P. (1996). A course in language teaching; Practice and theory. United Kingdom. UK: Cambridge University Press.

Wells, P. K., de Lange, P. A., \& Fieger, P. (2008). Integrating a Virtual Learning Environment into a Second-Year Accounting Course: Determinants of Overall Student Perception. Accounting \& Finance, Vol. 48(3), hal: 503-518.

Wiginton, L. B. (2013). Flipped Instruction: an Investigation into the Effect of Learning Environment on Students Self-efficacy, Learning style, and Academic Achievement in an Algebra 1 Classroom. [Thesis]. USA: The University of Alabama.

Yin, R. K. (2009). Case Study Research; Design and Methods. SAGE Publications, Thausand Oaks, hal: 240 